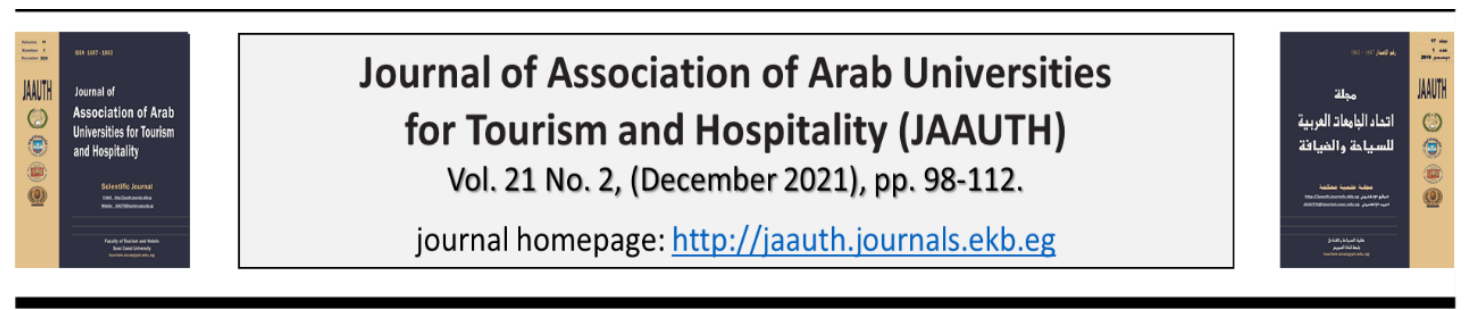

\title{
Representation of the King in the Henu Praise on the Egyptian Temples During the Graeco-Roman Period
}

\section{Heba Magdy}

Associate professor, Faculty of Tourism \& Hotels, Alexandria University, Egypt

\section{ARTICLE INFO}

Keywords:

Souls of pe and

Nekehn; Henu praise;

Egyptian temples.

\section{(JAAUTH) \\ Vol. 21, No. 2, (December 2021), PP.98-112.}

\section{ABSTRACT}

The souls of Pe and Nekhen used to be depicted in the Henu posture. It is done by striking the chest with a fest while raising the other arm, while kneeling on one knee. This praise was done to greet the new-born sun or celebrate the animated soul of the king during "the recitation of Glorifications" ritual. The king was represented in the Henu posture during the Pharaonic period in the tombs. However, he was rarely represented in this posture on the walls of the temples. In the late period, statues of the kings in this posture appeared. During the Graeco-Roman period, the king was more frequently represented in this posture on the walls of the temples, precisely on the doors and windows. It could be an imitation of the souls of Pe and Nekhen that used to be represented flanking the doors the mortuary temples of the Old Kingdom.

\section{1- Introduction}

The Henu posture is one of the traditional postures that appeared in ancient Egypt. It is done by striking the chest with a fest while raising the other arm. It can be done standing but is traditionally made knelling on one knee. It demonstrates obedience and submission before a god. This posture used to be done in a praise by the souls of Pe (Buto in lower Egypt) and Nekhen (Hierakonpolis, Upper Egypt). the souls of Pe are shown with the heads of falcons, and the souls of Nekhen with those of Jackals. This praise was done to greet the new-born sun in the sky or celebrate the animated soul of the king during "the recitation of the Glorifications" ritual. The souls symbolized the old rulers of Buto and Hierakonpolis that support the living king and serve the deceased king by helping him to ladder in the sky (Wilkinson, 1999: 17).

There is only one detailed study concerned with the Henu praise: Ayman Mohamed Ahmed, "The concept of henu: gesture of praise and veneration in Ancient Egypt: multiple meanings in a single gesture", PhD Thesis, 2015. However, this study didn't deal with the Graeco-Roman era.

During the Pharaonic period, the henu praise was performed inside both the tombs and the temples. This praise was done either by the priests or the souls of Pe and Nekhen. All scenes of the henu praise found in the temples were done by the priests and is considered one of the stages in the process of the daily rituals. This appeared in the temple of Karnak and temple of Abydos (Ayman, 2015: 106). 
As for the representation of the king performing this praise during the Pharaonic period, is considered rare. The king was represented on the walls of the tomb of Ramses I (KV 16), sarcophagus chamber, west wall (Fig.1). He is knelt making the ritual Henu gesture between the souls of Pe and Nekhen. The text above the scene : "Words spoken by the Powers of Pe when they cheer the Horus of the horizon, their son, the Osiris-king Men-Pehty-Ra, son of the sun, Ra-Mes-Su, justified like one them. Words spoken by the Powers of Nekhen when they cheer the Lords of the Eternity and the Osiris-king, Lord of the Two Lands, Men-Pehty-Ra, justified like one of them."

The King appeared also in this posture accompanied by the souls of Pe and Nekhen in the Opet festival. Amenhotep III mentioned in his description of the Amun-Userhet (Collier, 2013) : " The souls of Pe performed a dance of jubilation for it, and the souls of Nekhen adored it" (Baines, 2006: 261-302). On the interior west wall of the Hypostyle Hall at Karnak temple, in the first register, (Fig.2) (Lergain, 1929) below this shrine on the left side of the hull is a kneeling figure of Ramses II in front of three jackal-headed figures, with hands in the position of jubilation, symbolic of the souls of Nekhen. while in the corresponding position on the right side of the hull the king is accompanied by three hawk-headed figures, in the same posture, representing the souls of Pe. (Seele, 1940: 70) another scene dates back to the reign of King Ramses III is depicted on the northern wall of the second court of the temple of Medinet Habu. The scene portrays the king offering offerings to the barque of the holy Theban triad. In the middle of side facing the spectator, three of Pe spirits are found at the bottom. They are in $h n w$ gesture and are headed by the king and the same gesture (Ayman, 2015: 145).

The king appeared also in the Henu gesture accompanied by the souls of Pe and Nekhen in the Valley festival. The king is depicted before three spirits of Pe or Nekhen in $h n w$ gesture. They are cheering and glorifying the deity during the festival. The scene appeared on the temple of Sety I at Qurna (Ayman 2015: 147)

However, the King didn't appear in this posture on the walls of the temples accompanying the souls of Pe and Nekhen in any other rite. It seems in somehow that the king appeared only in this posture if it is connected to the bark of Amun whether in the Opet festival or the Valley festival. This shape appeared on a granite bark stand in the temple of Amun at Jebel Barkal (Fig.3). The stand is preserved in the Museum of fine Arts in Boston (Inv. 23.728). In the Upper register, the goddess Meret of Upper Egypt (at left, wearing lilies on Her head) followed by king Atlanersa (wearing the skullcap with the Two Uraei) and by the three ' $B 3 w$ '-Souls of NekhenHierakonpolis represented in the kneeling jubilation position. (Museum of Fine Arts, Inv. 23.728)

During the Late Period statues of Pharaohs started to appear, although rare, in the Henu gesture. There are five bronze statues of this type, date back to the $26^{\text {th }}$ dynasty (Josephson, 1997: 33-39). One of them is preserved in the British Museum (Inv.N.

\footnotetext{
${ }^{1}$ A ship was made out of cedar and used to transport the sacred images of the gods of the Theban triad during festivals. It was gilded and decorated with precious stones. The Amun-Userhet (and its smaller portable version) played a key part in several festivals celebrated during the New Kingdom.
} 
EA11497) (Fig.4). It represents the king performing the Henu accompanied by the soul of Pe and that of Nekhen. The other one is preserved in Royal-Athena Gallery at New York (Fig.5).

The reason of the appearance of the king always accompanied by the souls of Pe and Neken, could be related to the consideration of these souls as the predynastic rulers of the northern and southern kingdoms of Egypt. Thus, the kings of historical times may have linked themselves to these legendary leaders and these two cities and their gods to appear as the rightful successors of their ancestors who ruled these two cities. (Zainab Abd el-Twab, 2018: 15). Other scholars thought that the souls of Neken and Pe were symbols of various groups of gods associated with these cities. Their connection with the king came from their role in providing the king with the necessary protection and power to overcome his enemies in battle, protecting and assisting the king in the renewal of his powers and ability to uphold Maat, as well as ensuring the continuous provision of offerings (Van Sittert, 2019:105).

It was not until the Graeco-Roman period that the king started to be represented in the henu gesture accompanied with the souls of Pe and Nekhen on the walls of the temples with no relation to the festival of the Opet or the Valley. The aim of the research is to trace the depiction of the king in this posture during the Graeco-Roman period.

\section{2- Methodology}

The researcher's methodology requires gathering relevant data from the specified documents to analyse the material and arrive at a more complete understanding of the king's depiction in Henu gesture. The researcher depends in gathering data on the scenes of the Egyptian temples that were built during the Graeco-Roman Period: Dendara, Esna, Edfu, Kom Ombo, Philae, Hibis at Kharga Oasis, temple of Hathor at Deir el-Madina, the Temple of Opet at Karank, the temple of Tod, the temple of Emrant, and the temple of Athribis. The scenes were only found in five temples.

\section{3- The Graeco-Roman era}

During the Graeco-Roman era, the souls of Pe and Nekhen were represented on the walls of the temples performing the henu praise before the god, accompanied by the king. This posture appeared in the following temples:

\subsection{Temple of Hathor at Deir el-Madineh:}

King (Ptolemy VI Philometor) is represented among the souls of Pe and Neken on the interior door of the southern chapel (B), the eastern side (Du Bourguet, 2002) (fig.6).
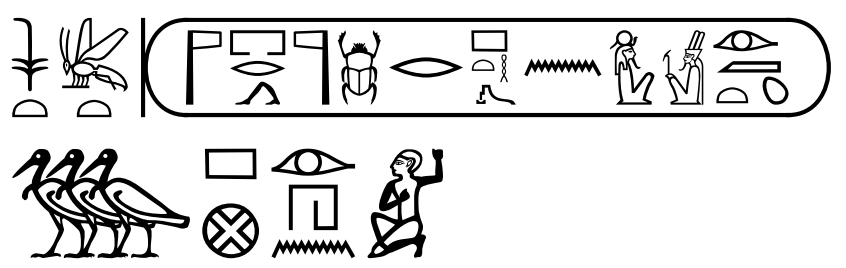

Nswt bity iwe ntrwy pr.wi stp n Pth-hprr ir(w) m3't Imn-Re b3.w $P \operatorname{ir}(. w) h n(w)$ 
"King of Upper and Lower Egypt (The heir of the two gods, the elect of Ptah-Khépri, the one who accomplishes the justice of Amon-Re)".

Souls of Pe accomplish the Henu ritual.
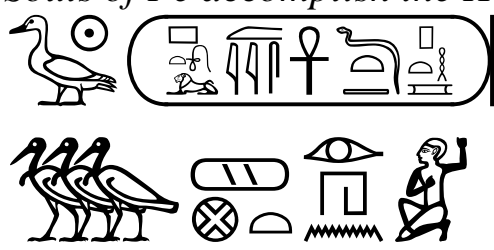

s3 $R^{\top}$ ptwlmys ${ }^{\text {enh }}$ d.t mry Pth

b3.w Nhn $\operatorname{ir}(. w) h n(w)$

Son of Re (Ptolemy, live forever, beloved of Ptah)

Souls of Nekhen accomplish the Henu ritual. (Temple of Deir el-Madineh online database)

\subsection{Opet temple at Karnak}

In the central hall (VII), southern wall to the left of the door, in the $5^{\text {th }}$ register (Fig.7), king Ptolemy VIII is representing in the henu posture (Karnak Project online database: Cfeetk 178305) accompanied with the following inscription:
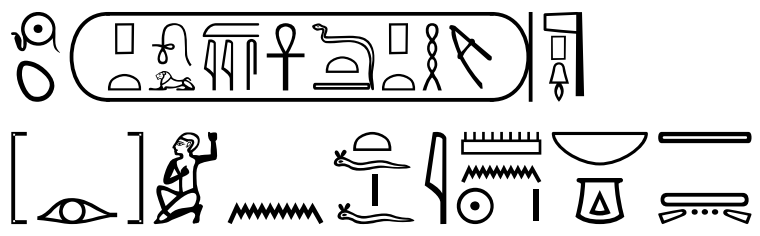

s3-r` ptwlmys `nhshh-dt-mry-Pth $p 3\left({ }^{(}\right)$ntr mnsh (iri) hnw n it-f'Imn-R` nb-nswt t3-`wy

The son of Re, Ptolemy-may-he-live-to-ever-loved-of-Ptah, the god Everget, [makes] henu for his father, Amon-Re, master of the thrones and the two lands. (De Wit, 1968: 41)

The scene here is a continuation of the scenes of the souls of Nekhen. (Karnak Project online database: Cfeetk 78103)

\subsection{Temple of Dendara}

In the shrine on the roof of the temple, precisely on the western embrasure of the third window, the king is represented performing the Henu accompanied by the souls of Nekhen. While on the eastern embrasure of the first window, a repetition of the previous scene appeared but with the representations of the souls of Pe (Fig.8) (Dend.VIII, 140-142). Thus, we can suppose that the lower register should have a depiction of the king performing the Henu (Chassinat, 1978: 140-142).

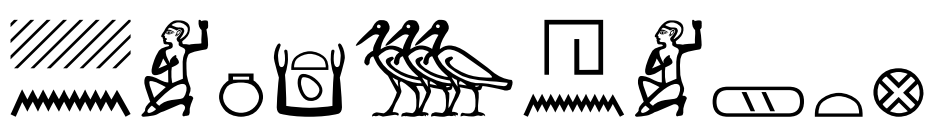

hnw $n$ k s.t b3w hnw nhn

"Jubilation to your Ka, the souls of Nekhen"

\subsection{Temple of Edfu}


- On the northern door of the court of the mammisi of Edfu, king Ptolemy VIII is represented performing the henu accompanied by the souls of Nekhen in front of the falcon-god Horus (Fig.9). (Chassinat, 1939: 193)
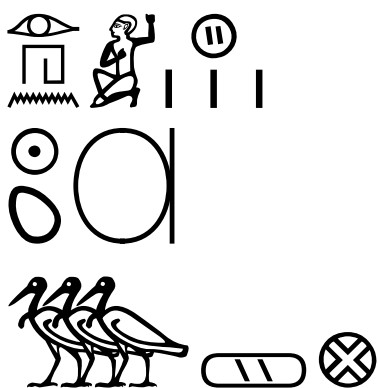

N10

\author{
iri hnw \\ $53 R^{e}$ \\ b3.w Nhn \\ $h r s 33 s t$
}

"Performing the Henu, son of Re ( ), with the souls of Nekhen, to Horus son of Isis".

- On the right side of the central door in the pylon, the king (could be Ptolemy XII) is represented wearing the blue crown and performing the henu accompanied by the souls of Pe in front of god Horus (Edfou, VIII, 14).
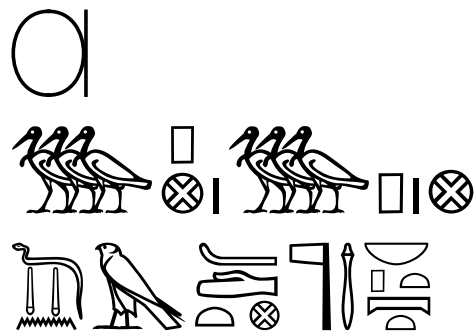

b3w P, dd mdw in hr Bhdti ntr ${ }^{3} \mathrm{nb} p t$

"The souls of Pe, Word spoken by Horus Behedeti, the great god, lord of the sky"

On the left side of the same door, the king is represented performing the Henu accompanied by the souls of Nekhen in front of god Horus (Edfou, VIII, 22) (Fig. 10). (Chassinat, 1933: 14, 22)

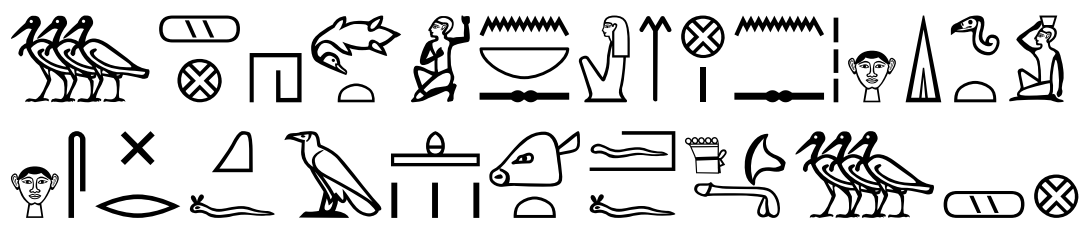

b3w Nhn h3 snd $n$ nb.sn nswt m tp n.sn hrr rdt nrw.f hr swr kf3t.f hnt Geit.f $d r$ b 3 h h

"The souls of Nekhen who salute their lord (with the king) by spreading respect for him and increasing his reputation in his place (Edfu)"

\subsection{Temple of Philae}


- On the thickness of the doorway leading to the "Mammisi" (First Pylon, west tower), west side, detail from the second register from above: Ptolemy VI Philometor is represented wearing the blue crown and performing the Henu before Hathor accompanied by the souls of Pe and Nekhen (Fig.11) (Junker, 1958: Abb. 140).

- In the western colonnade, on the lintel of the north gate, the King with empty cartouche (could be Ptolemy XII) is represented performing the henu dance before the enthroned Osiris and Isis. The text that accompanied the scene reads (Phila III, 164):

niswt bit (.........) p.t p.t wr.w nn n.w t3 $r$ 3 w.f h $r$ iri(.t) hnw $n$ ḥk3.w n.w t3

"King of Upper and Lower Egypt (.........), and Pat-people, the greatest of the whole country, perform the henu for the master of the lands".(Kockelmann, 2016: 164)

On the same previous place, the scene is completed to see the King with also an empty cartouche represented kneeling performing the henu dance in front of the enthroned Harendotes and Hathor (Fig.12). The text that accompanied the scene reads (Phila III, 170):

"Son of Re (..........), and the Rechit people, the Great one, who the sun shines through. Perform the worship of the kings of the land". (Kockelmann, 2016: 170)

\section{4- Results}

- The Henu praise used to be done during the Pharaonic period by the priests or by the souls of Pe and Nekhen and it was related to different rites. The King during the Pharaonic period appeared accompanying those souls on the walls of the tombs. As for the temples, the pharaoh appeared only in this gesture flanking the bark of Amun during the Opet or the Valley festival. During the Late period, statues of the king in the Henu gesture started to appear.

- The presence of the king accompanied by these souls could be related to the desire of the king to be linked to these legendary leaders to appear as the rightful successors of their ancestors who ruled these two cities. Or it could be related to the desire of the king to be connected with the souls of various groups of gods associated with these cities, who could provide him with the necessary protection and power to overcome his enemies in battle, protecting and assisting the king in the renewal of his powers and ability to uphold Maat, as well as ensuring the continuous provision of offerings.

- During the Graeco-Roman period the King was represented performing the Henu praise on the Egyptian temples. The researcher spotted seven scenes in the following temples: Deir el-Madineh, Opet at Karnak, Edfu, and Philae. All of them date back to the Ptolemaic period (table 1). 


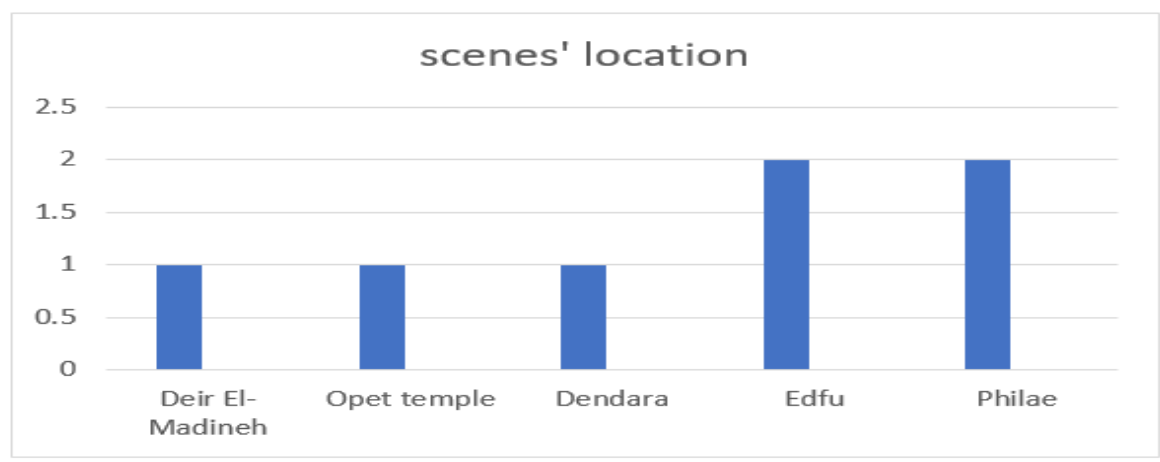

- All the scenes appeared on the gates and doors, or ?s inside the temples. The souls of Pe and Nekhen used to be represented flanking the false doors or the real doorway in the mortuary temples of the Old Kingdom (Sahura, Unis, Merenra, Pepy II). (Cwiek, 2003: 269) Thus, the depiction of these souls on the gates and doors in the Graeco-Roman era could be an imitation of older representations.

- All the scenes representing the king before the deity except for three scenes: in the temple of Deir el-Madineh, in the Opet temple, and Dendara temple.

- There are only two scenes in the temple of Philae where the king is not represented accompanied with the souls of Pe and Nekhen, but with the Pat and Rechit people. The Rechit is considered as a city in Northern Delta. Later, its people were regarded as being the representation of Seth. (Wolfgang, 1968: 20, 42) In the Language the word used to refer to the defeated people. (Vomberg, 2006: 1448) It could also to the infer sector of the society that contains peasants. While, Pat is regarded to be controlled by Horus. In the language it could be also refer to the elite sector of the Society. Thus, the ancient Egyptian Society consists three sectors: Rechit (the infer sector), the Pat (the elite), and the Henmemet (the highest class). (Griffin, 2007) It seems that in the scene here, the Rechit and the Pat replaced the shape of the souls of Nekhen and Pe. Thus, they refer here to the people of Upper and Lower Egypt. 


\section{5- References}

- Ayman M. (2015), The concept of henu: gesture of praise and veneration in Ancient Egypt: multiple meanings in a single gesture, PhD Thesis, University of Oviedo.

- Baines J. (2006),"Public Ceremonial Performance in Ancient Egypt." In: Takeshi and Lawrence S. Coben Inomata (eds.), Archaeology of Performance, Lanham, MD: AltaMira Press, 261-302.

- Chassinat E. (1933), Le temple d'Edfou. Tome. 8. Le Caire (MMAF ; 25).

- Chassinat E. (1939), Le mammisi d'Edfou. Memoires publies par les membres de l'Institut français d'archéologie orientale 16, Institut français d'archéologie orientale, Caire.

- Chassinat E. (1978), Le temple de Dendara, Tome. VIII, Caire.

- Collier M. (2013). Ship of the god: The Amun-Userhet in New Kingdom Egypt, thesis, Texas University.

- Cwiek A. (2003), Relief decoration in the royal funerary complexes of the Old Kingdom, $\mathrm{PhD}$ Thesis, Warsaw University.

- De Wit C. (1968). Les inscriptions du temple d'Opet, à Karnak. III., Traduction intégrale des textes rituels. Essai d'interprétation, BiAeg 13.

- Du Bourguet P. (2002). Le temple de Deir El-Medina, IFAO, Caire.

- Griffin K. (2007), "An Analysis of the Entities Present on the Columns Within the Temple of Ramesses II at Abydos", Current Research in Egyptology, Leiden.

- Josephson J.A (1997). Egyptian Royal Sculpture of the Late period, 400-246 BC, Mainz.

- Karnak Project online database www.sith.huma-num.fr/Karnak/5674 Cfeetk 178305

- Kockelmann Von Holger \& Winter E. (2016). Philae III: Die Zweite Ostkolonnade des temples der Isis in Philae, Teil 2.

- Lergain (1929). Les temples de Karnak. Fragment du dernier ouvrage de Georges Legrain, Directeur des Travaux du Service des Antiquités de l'Égypte, Bruxelles.

- Museum of Fine Arts, Inv. 23.728 online database https://collections.mfa.org/objects/145116/boat-stand-of-king-atlanersa?ctx=809bb87bb14f-4538-a77e-d33c5e5c3d2f\&idx=4

- Seele K.C. (1940) The coregency of Ramses II with Seti I and the date of the Great Hypostyle hall at Karnak, the oriental institute of the university of Chicago.

- Temple of Deir el-Madineh online database http://projetrosette.info/page.php?Id=799\&TextId=85\&line $=240 \&$ bloc $=2 \&$ langue $=$ FR

- Van Sittert B. (2019). Maintaining order over Chaos: A study of the ba and baw concepts in the predynastic period, early dynastic period, and Old Kingdom, Master's thesis, the American University in Cairo.

- Vomberg P. (2006). "Sonderzeichenliste", In: Rainer Hannig (ed.) Großes Handwörterbuch Ägyptisch-Deutsch (2800 - 950 v. Chr.), Mainz, 1448.

- Wilkinson, H. R. (1999). Symbol and Magic in Egyptian Art, London: Thames \& Hudson Ltd.

- Wolfgang H. (1968). Geschichte des Alten Ägypten, Bd. 1, Abschnitt 3. Brill, Leiden.

- Junker H. \& Winter E. (1958). Phila I: Der grosse Pylon des Temples der Isis in Philae, Wien.

- Zainab Abd El-Tawab (2018). "Spiritual and Ancestral worship in Egypt during Prehistoric and early dynastic period", In: Journal of minbar ettourath, issue 7, Algeria, PP. 5-24. 


\section{Table 1}

Scenes of the king performing the Henu praise

\begin{tabular}{|c|c|c|c|c|c|}
\hline N. & Temple & $\begin{array}{c}\text { Location of } \\
\text { the scene }\end{array}$ & Date & Description & Deity \\
\hline 1 & $\begin{array}{l}\text { Temple of } \\
\text { Hathor Deir } \\
\text { el-Madineh }\end{array}$ & $\begin{array}{l}\text { interior door of } \\
\text { the southern } \\
\text { chapel (B) }\end{array}$ & $\begin{array}{l}\text { Ptolemy } \\
\text { VI }\end{array}$ & $\begin{array}{l}\text { King accompanied } \\
\text { souls of Pe and } \\
\text { Nekhen }\end{array}$ & None \\
\hline 2 & \begin{tabular}{|c|} 
Opet \\
Temple, \\
Karnak \\
\end{tabular} & $\begin{array}{l}\text { Door of the } \\
\text { central hall }\end{array}$ & $\begin{array}{l}\text { Ptolemy } \\
\text { VIII }\end{array}$ & $\begin{array}{l}\text { King accompanied } \\
\text { souls of Pe and } \\
\text { Nekhen }\end{array}$ & None \\
\hline 3 & Dendara & $\begin{array}{l}\text { Window in the } \\
\text { shrine on the } \\
\text { roof of the } \\
\text { temple }\end{array}$ & $\begin{array}{l}\text { Ptolemaic } \\
\text { period }\end{array}$ & $\begin{array}{l}\text { King accompanied } \\
\text { souls of Pe and } \\
\text { Nekhen }\end{array}$ & None \\
\hline 4 & Edfu & $\begin{array}{l}\text { Door of the } \\
\text { court of the } \\
\text { mammisi }\end{array}$ & $\begin{array}{l}\text { Ptolemy } \\
\text { VIII }\end{array}$ & $\begin{array}{l}\text { King accompanied } \\
\text { souls of Pe and } \\
\text { Nekhen }\end{array}$ & Horus \\
\hline 5 & Edfu & $\begin{array}{l}\text { Central door in } \\
\text { the pylon }\end{array}$ & $\begin{array}{l}\text { Ptolemy } \\
\text { XII }\end{array}$ & $\begin{array}{l}\text { King accompanied } \\
\text { souls of Pe and } \\
\text { Nekhen }\end{array}$ & Horus \\
\hline 6 & Philae & $\begin{array}{l}\text { Door leading to } \\
\text { the mammisi in } \\
\text { the pylon }\end{array}$ & $\begin{array}{l}\text { Ptolemy } \\
\text { VI }\end{array}$ & $\begin{array}{l}\text { King accompanied } \\
\text { souls of Pe and } \\
\text { Nekhen }\end{array}$ & Isis \\
\hline 7 & Philae & $\begin{array}{l}\text { North gate in } \\
\text { the western } \\
\text { colonnade }\end{array}$ & $\begin{array}{l}\text { Ptolemy } \\
\text { XII }\end{array}$ & $\begin{array}{l}\text { King accompanied } \\
\text { Pat and Rechit }\end{array}$ & \begin{tabular}{|c|}
$\begin{array}{c}\text { Isis and } \\
\text { Osiris }\end{array}$ \\
Harendotes \\
and Hathor
\end{tabular} \\
\hline
\end{tabular}

\section{Figures}

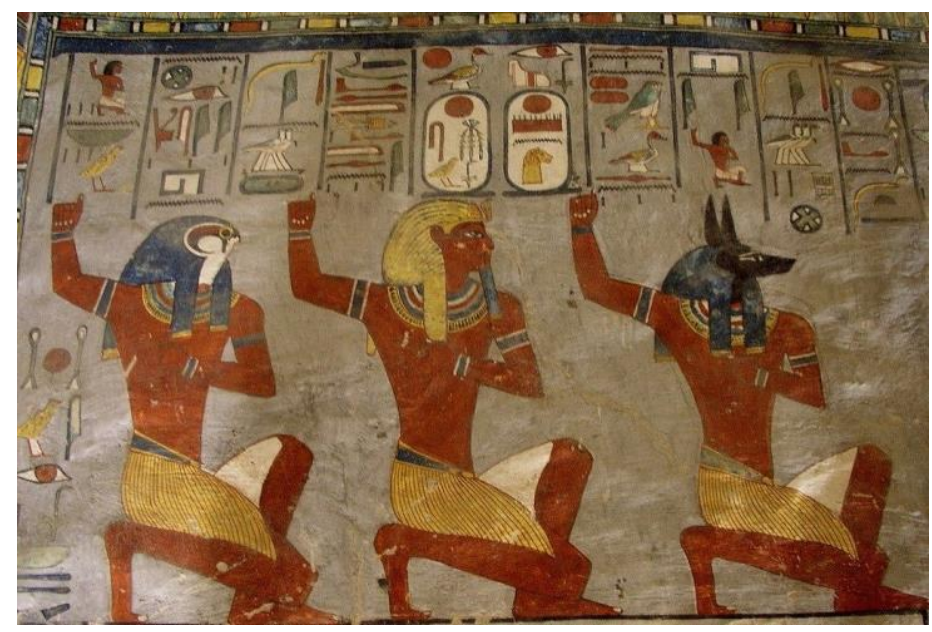

Fig.1. tomb of Ramses I (KV 16), sarcophagus chamber, west wall 

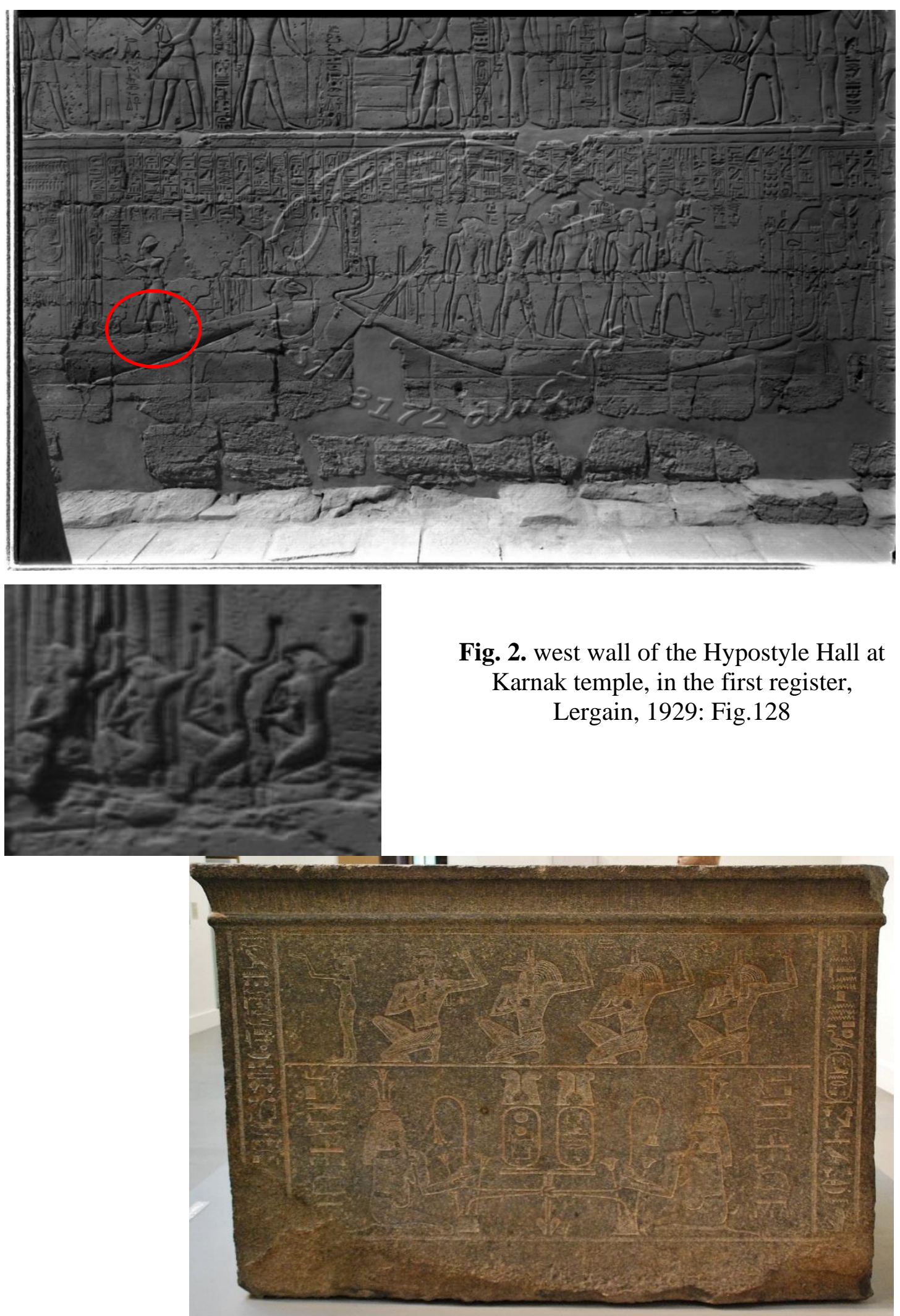

Fig.3. granite bark of Amun, Museum of fine Arts in Boston (Inv. 23.728). 


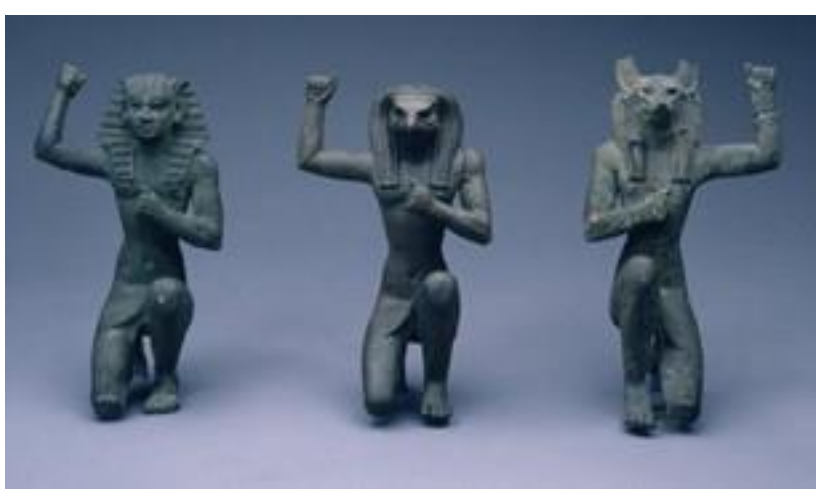

Fig.4. Bronze statue,

British Museum (Inv.N. EA11497)

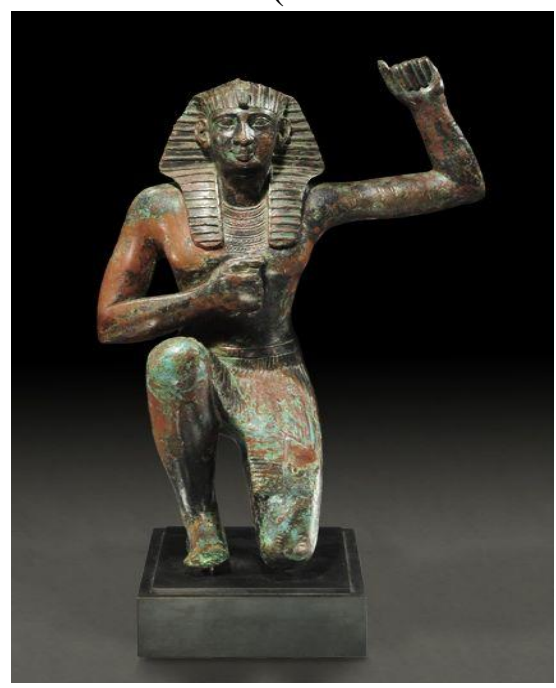

Fig.5. Bronze statue

Royal-Athena Gallery at New York

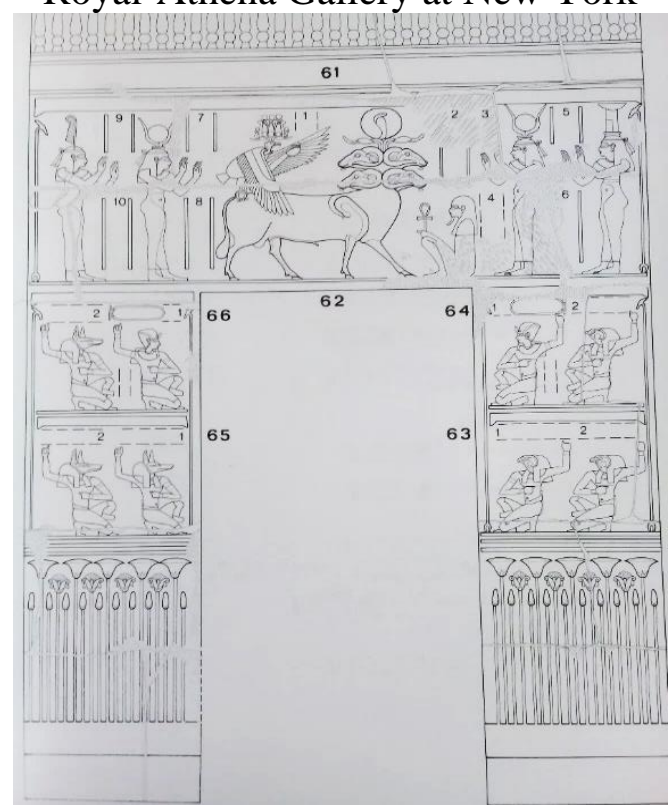

Fig.6. interior door of the southern chapel (B), Temple of Hathor, Deir el-Madineh $\mathbf{1 0 8} \mid \mathrm{P}$ a g e 

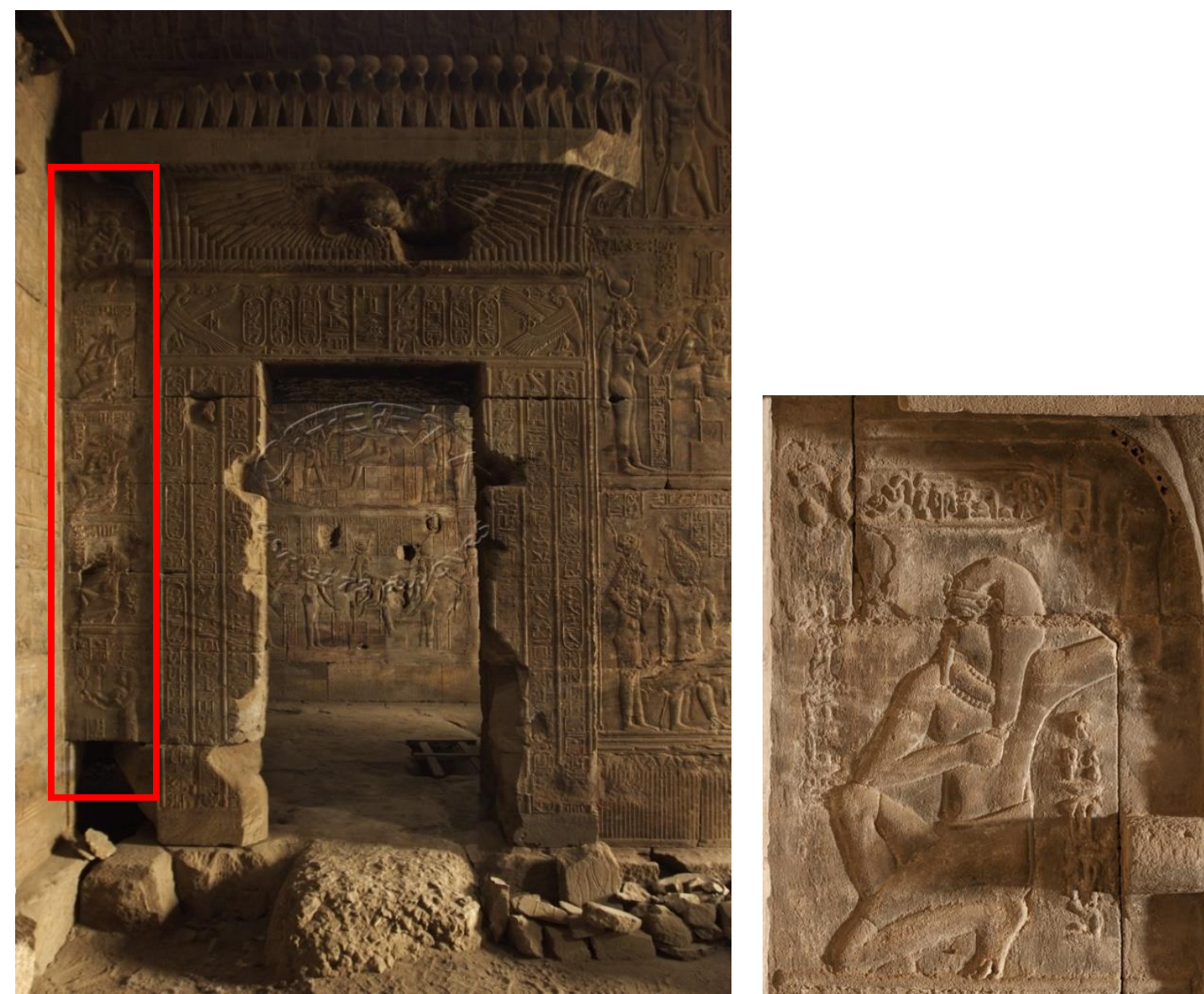

Fig.7. central hall (VII), southern wall to the left of the door, Opet Temple, Karnak
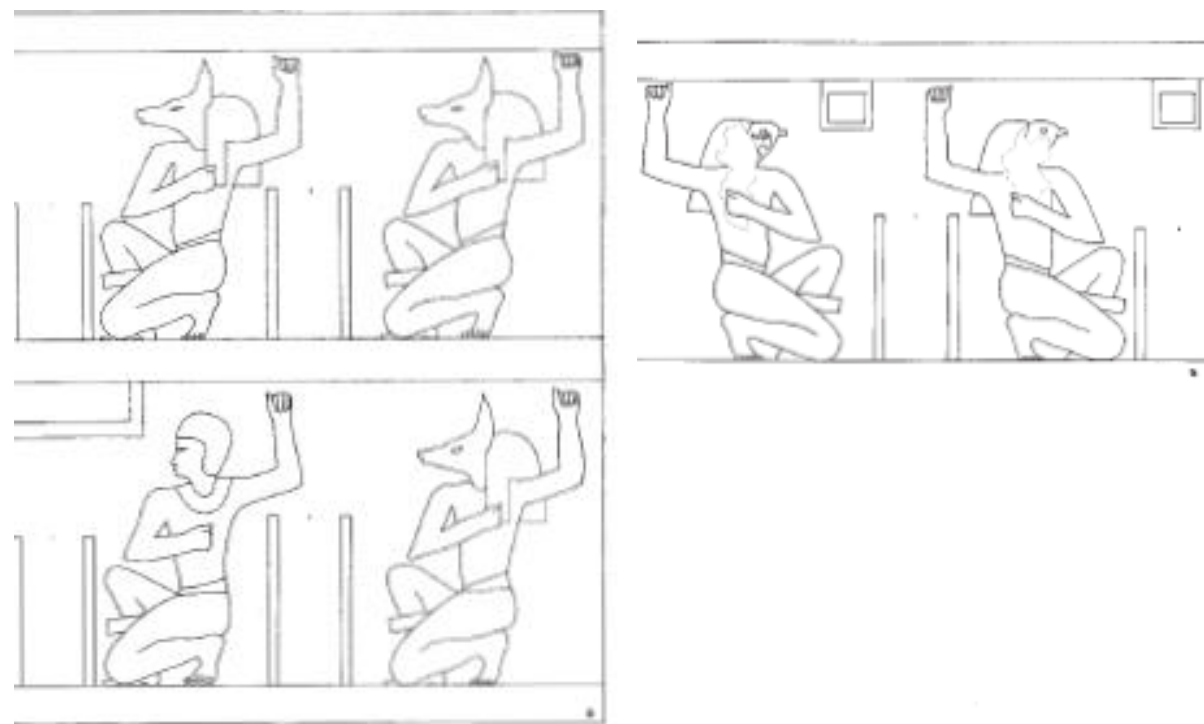

Fig.8. Temple of Dendara, Shrine on the roof, Chassinat (1978), Pl. DCCCX. 


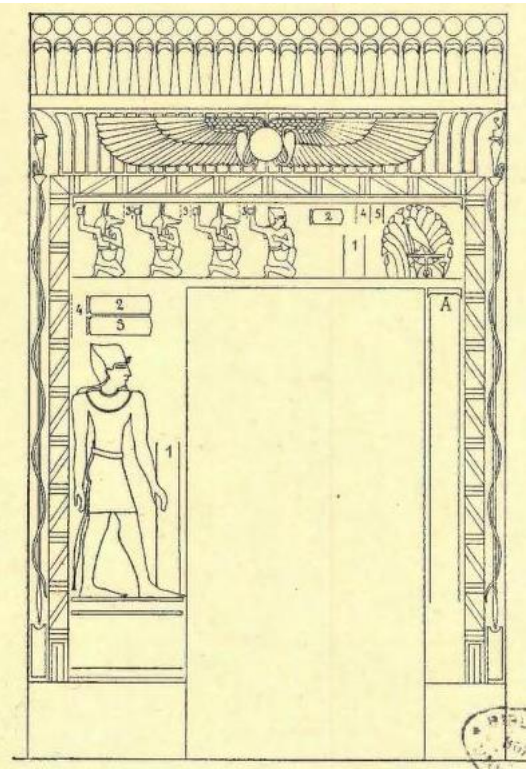

Fig.9. court of the mammisi, Edfu Temple, Chassinat (1939), Pl. LI (2).

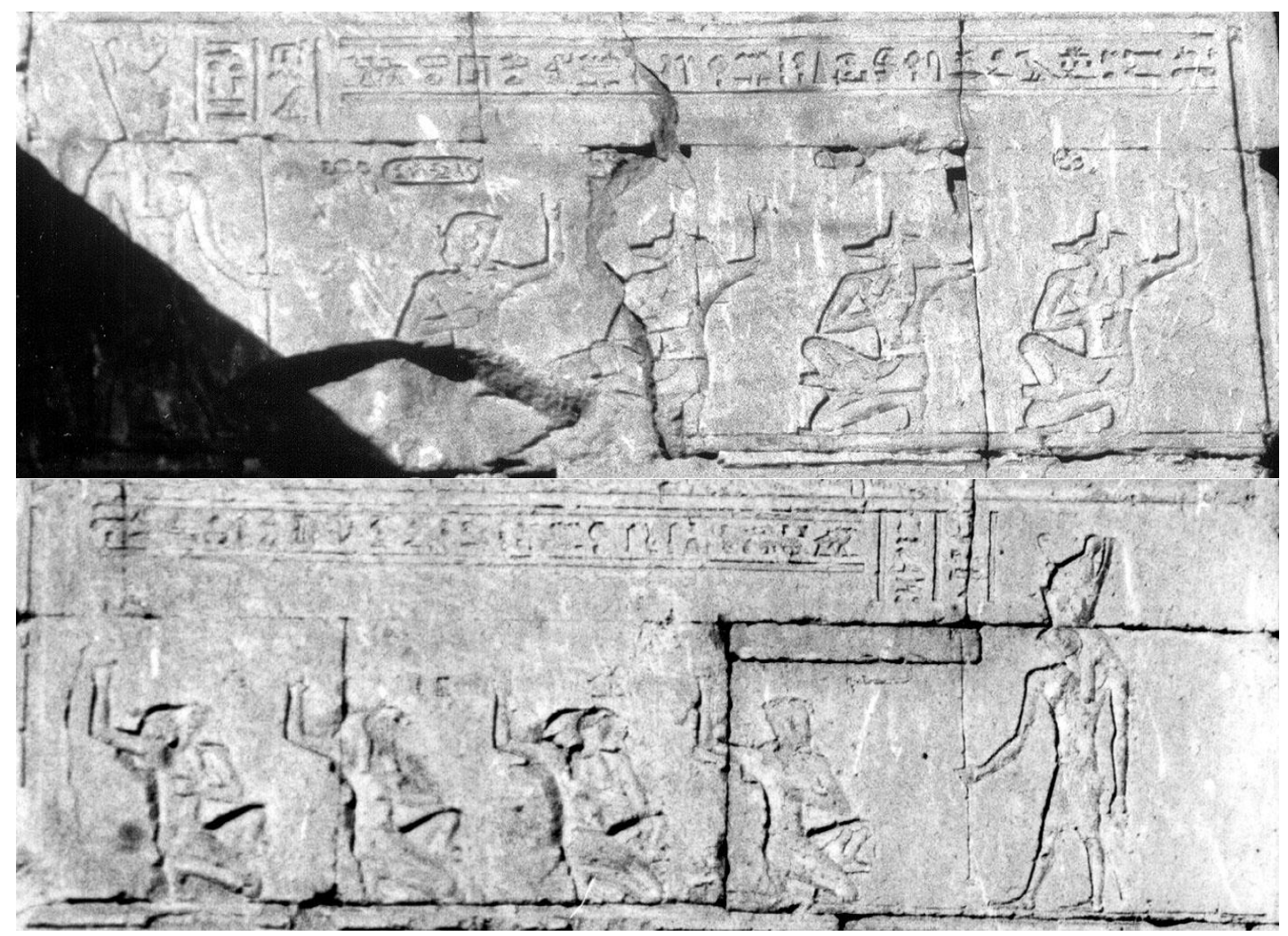

Fig.10. central door in the pylon, Edfu Temple, Chassinat (1933), pl. 179. 


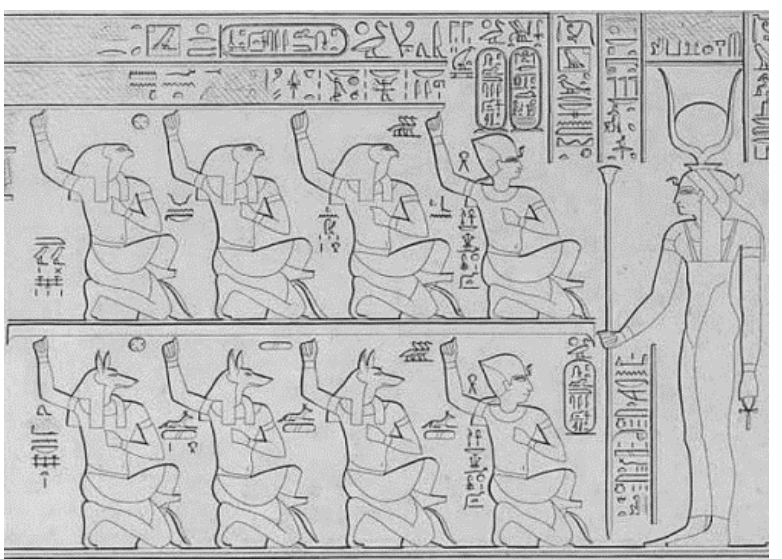

Fig. 11. First Pylon, west tower, Philae Temple, Junker H. \& Winter E. (1958), Abb. 140.
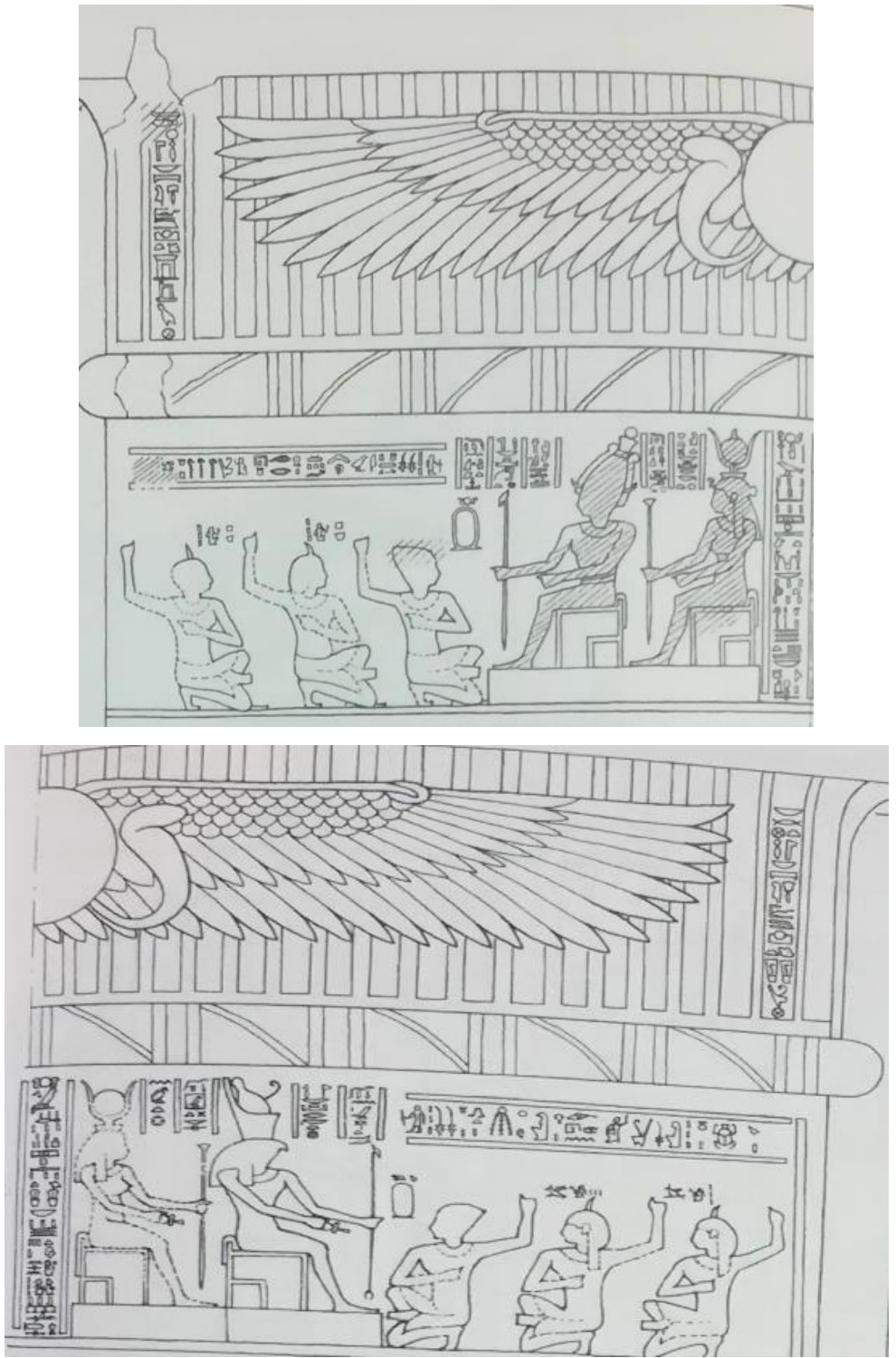

Fig.12. North gate, western colonnade, Philae Temple, Kockelmann (2016), tafeln, No. 69. 


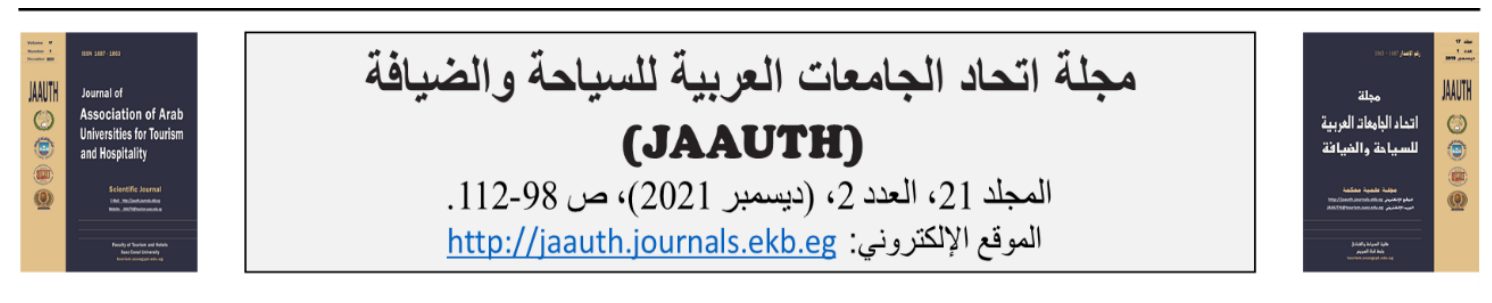

\section{تصوير الملك في وضع الحنو على المعابد المصرية في العصر اليوناني - الروماني هبة مجدي}

أستاذ مساعد، كلية السياحة والفنادق، جامعة الإسكندرية هابة

\begin{tabular}{|c|c|}
\hline الملخص & معلومات المقالة \\
\hline 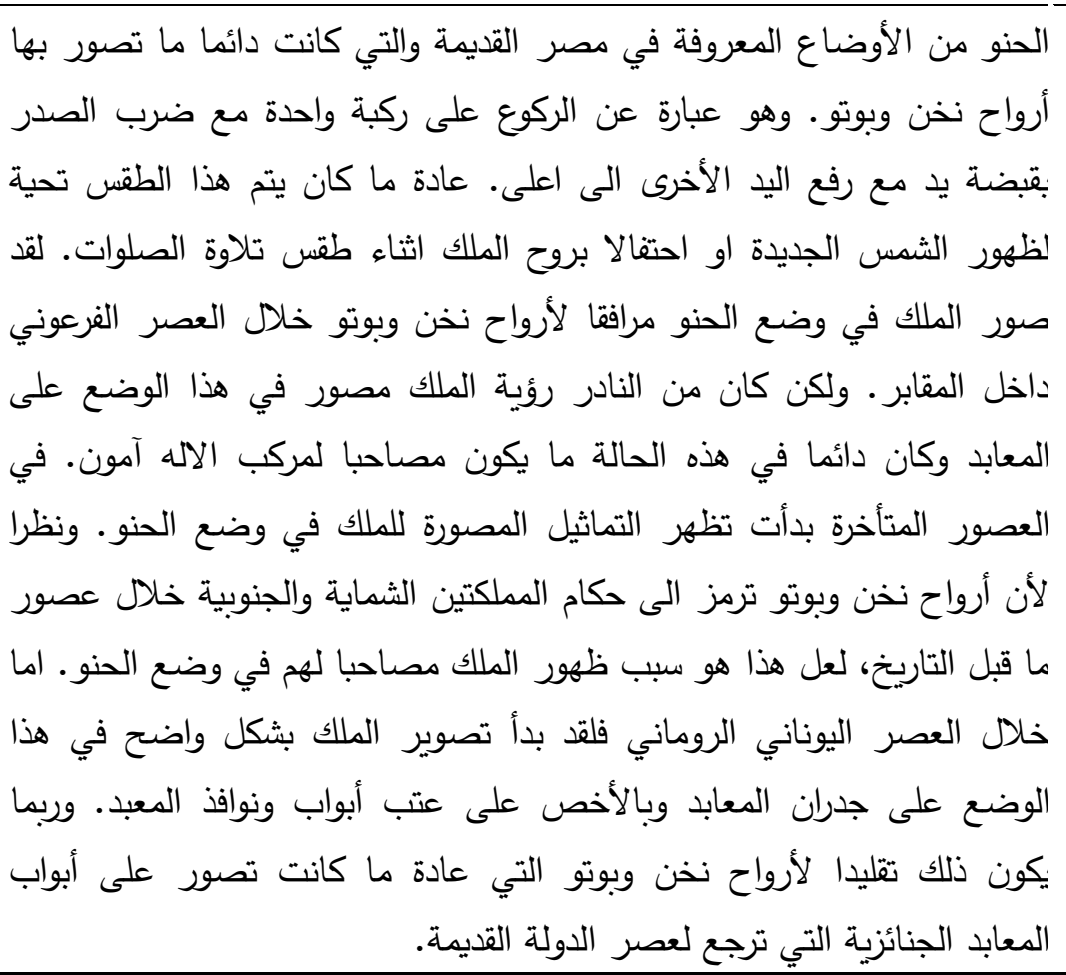 & 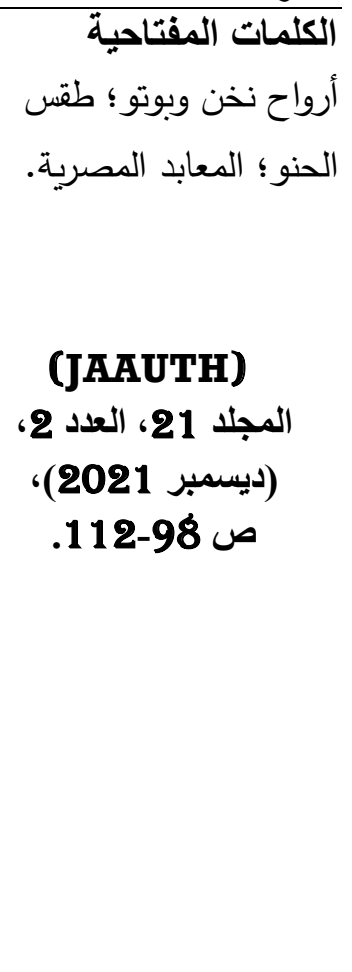 \\
\hline
\end{tabular}

